\title{
STAPHYLOCOCCUS AUREUS IN NURSING PROFESSIONALS AND THE MICROORGANISM'S SUSCEPTIBILITY PROFILE TO ANTIMICROBIALS ${ }^{1}$
}

\author{
Letícia Pimenta Lopes², Daiana Patrícia Marchetti Pio ${ }^{3}$, Lílian Andreia Fleck Reinato ${ }^{4}$, Gilberto Gambero Gaspar ${ }^{5}$, \\ Marinésia Aparecida do Prado ${ }^{6}$, Elucir Gir ${ }^{7}$
}

${ }^{1}$ Study carried out with support from the Conselho Nacional de Desenvolvimento Científico e Tecnológico (CNPq), under protocol no. $476480 / 2012$.

2 Ph.D. in Nursing. Graduate Program in Fundamental Nursing, Escola de Enfermagem de Ribeirão Preto (EERP), Universidade de São Paulo (USP). Ribeirão Preto, São Paulo, Brazil. E-mail: letylopes@yahoo.com.br

${ }^{3}$ Doctoral student, Interunits Doctorate Program in Nursing, EERP/USP. Ribeirão Preto, São Paulo, Brazil. E-mail: daiana_pio@ yahoo.com.br

${ }^{4}$ Doctoral student, Graduate Program in Fundamental Nursing, EERP/USP. Ribeirão Preto, São Paulo, Brazil. E-mail: lilianandreiafleck@gmail.com

${ }^{5}$ Ph.D. in Clinical Medicine. Assistant physician, Hospital das Clínicas Faculdade de Medicina de Ribeirão Preto, USP. Ribeirão Preto, São Paulo, Brazil. E-mail: gilbertogambero@terra.com.br

${ }^{6}$ Ph.D. in Nursing. Professor, Universidade Federal de Goiás. Goiânia, Goiás, Brazil. E-mail: marinesiaprado@gmail.com

${ }^{7}$ Ph.D. in Nursing. Professor, Department of General and Specialized Nursing, EERP/USP. Ribeirão Preto, São Paulo, Brazil. E-mail: egir@eerp.usp.br

\section{ABSTRACT \\ Objective: to identify the carrier's state and the susceptibility profile of Staphylococcus aureus isolated from saliva and nasal secretion of nursing professionals to antibiotics. \\ Method: cross-sectional study that used saliva and nasal secretion samples of 100 nursing professionals who provide care for patients with HIV/Aids. \\ Results: forty-three percent of the participants presented positive saliva or nasal secretion samples for Staphylococcus aureus. Of the 74 nasal secretion samples with Staphylococcus aureus, $14.9 \%$ presented oxacillin resistance; $91.9 \%$ presented penicillin resistance; $44.6 \%$ presented erythromycin resistance, and $41.9 \%$ presented clindamycin resistance. Of the 12 positive saliva samples, $16.7 \%$ presented oxacillin resistance; $100.0 \%$ presented penicillin resistance; $33.4 \%$ presented erythromycin resistance, and $25.0 \%$ presented clindamycin resistance. \\ Conclusion: nursing professionals, once aware of their carrier state of multi-resistant microorganisms, will supervise their care practices and more efficiently adopt measures for prevention and control of the epidemiological chain of these bacteria in their work environment. DESCRIPTORS: Bacteria. Staphylococcus aureus. Methicillin resistance. Anti-bacterial agents. Nursing. Nursing staff. \\ STAPHYLOCOCCUS AUREUS EM PROFISSIONAIS DE ENFERMAGEM E O PERFIL DE SUSCETIBILIDADE DO MICRORGANISMO AOS ANTIMICROBIANOS}

\section{RESUMO}

Objetivo: identificar o estado de carreador e o perfil de suscetibilidade aos antibióticos dos Staphylococcus aureus isolados da saliva e da secreção nasal dos profissionais de enfermagem.

Método: estudo transversal, que utilizou amostras de saliva e secreção nasal, obtidas de 100 profissionais de enfermagem que assistem pessoas com HIV/aids.

Resultados: identificou-se que $43,0 \%$ dos participantes apresentaram amostras de saliva e/ou de secreção nasal positivas para Staphylococcus aureus. Das 74 amostras de secreção nasal com Staphylococcus aureus, 14,9\% apresentaram resistência à oxacilina; 91,9\% à penicilina; 44,6\% à eritromicina e 41,9\% à clindamicina. Das 12 amostras de saliva positivas, 16,7\% foram resistentes à oxacilina; 100,0\% à penicilina; 33,4\% à eritromicina e $25,0 \%$ à clindamicina.

Conclusão: o profissional ao obter conhecimento de seu estado de carreador de microrganismos multirresistentes, passará a supervisionar suas práticas assistenciais e adotar com mais eficiência as medidas para a prevenção e o controle da cadeia epidemiológica dessas bactérias no ambiente laboral.

DESCRITORES: Bactérias. Staphylococcus aureus. Resistência a meticilina. Antibacterianos. Enfermagem. Recursos humanos de enfermagem. 


\section{STAPHYLOCOCCUS AUREUS EN PROFESIONALES DE ENFERMERIA Y EL PERFIL DE SUSCEPTIBILIDAD DE LOS MICROORGANISMOS A LOS ANTIMICROBIANOS}

\section{RESUMEN}

Objetivo: identificar el estado del cargador y el perfil de susceptibilidad a los antibióticos de los Staphylococcus aureus aislados de la saliva y de la secreción nasal de los profesionales de enfermería.

Método: estudio transversal, que utilizó muestras de saliva y secreción nasal, obtenidas de 100 profesionales de enfermería que asisten a personas con VIH/SIDA.

Resultados: se identificó que 43,0\% de los participantes presentaron muestras de saliva y/o secreción nasal positiva por Staphylococcus aureus. De las 74 muestras de secreción nasal con Staphylococcus aureus, 14,9\% presentaron resistencia a la oxacilina; $91,9 \%$ a la penicilina; $44,6 \%$ a la eritromicina y $41,9 \%$ a la clindamicina. De las 12 muestras de saliva positivas, $16,7 \%$ fueron resistentes a la oxacilina; $100 \%$ a la penicilina; $33,4 \%$ a la eritromicina y $25,0 \%$ a la clindamicina.

Conclusión: se cree que el profesional al obtener conocimiento de su estado de portador del microorganismos multi-resistentes, pasará a supervisar sus prácticas asistenciales y adoptar con mayor eficacia las medidas para la prevención y el control de la cadena epidemiológica de estas bacterias en el ambiente laboral.

DESCRIPTORES: Bacterias. Staphylococcus aureus. Resistencia a la meticilina. Antibacterianos. Enfermería. Personal de enfermería.

\section{INTRODUCTION}

Healthcare professionals, especially nursing professionals, are considered a population susceptible to colonization by multi-resistant microorganisms in their work environment. Work activities performed by nursing professionals involve close physical contact with patients. This, associated with the lack of adherence to standard precautions, may favor the colonization and dissemination of microorganisms, with risk to cause infection outbreaks. ${ }^{1}$

National and international studies characterize healthcare professionals as a group vulnerable to the colonization by Staphylococcus aureus, in addition to potential disseminators of these microorganisms in their care activities. ${ }^{2-9}$

Asymptomatic carriers of Staphylococcus aureus may act as disseminators of the microorganism to a population susceptible to colonization..$^{10}$ Approximately $20 \%$ of the population may be considered persistent carriers, $60 \%$ transitory carriers, and the remaining $20 \%$ do not present colonization by Staphylococcus aureus. ${ }^{11}$ The highest rates of colonization may be found among healthcare professionals and individuals with immunological deficiency, such as those with HIV/Aids. ${ }^{12}$

An important characteristic of Staphylococcus aureus is the ability to acquire mechanisms of resistance to antibiotics. The indiscriminate use of antimicrobials, in addition to widely contributing to the maintenance and steady increase in the selection of resistant bacteria, constitutes a serious public health problem. ${ }^{13}$

The first report of methicillin-resistant Staphylococcus aureus (MRSA) occurred in 1961, one year after this semi-synthetic penicillin had been made available in the market. ${ }^{14}$ Since then, the MRSA is endemic in several hospitals, and this problem is no longer restricted to large hospitals and developing countries. ${ }^{15}$

The adherence of healthcare institutions to hospital infection control policies will favor the reduction of bacterial resistance. However, the main basic measures for prevention and control of hospital infections ${ }^{16}$ must be adopted by healthcare professionals in their care practice.

Knowledge on the condition of MRSA carrier is a right of healthcare professionals and must be considered a result of their work practice, rather than a criticism excuse. With the knowledge on their carrier state, professionals are expected to reflect better on their attitudes and work practices, aiming at better adherence to preventive measures. ${ }^{4}$

Due to the relevance of the theme, combined with the lack of national studies on the prevalence of methicillin-resistant Staphylococcus aureus, specifically with nursing teams, the present study was considered relevant, as its objective was to identify the carrier state of nursing professionals and the susceptibility profile of Staphylococcus aureus to antimicrobials, isolated from saliva and nasal secretion.

\section{METHOD}

A cross-sectional study was carried out in five hospitalization units of a teaching hospital in a city in the state of São Paulo. Of these, three units were destined for medical clinics and two were specialized in providing care to patients with HIV/Aids. These units were chosen because they regularly admit patients with HIV/Aids, both high and medium complexity patients, and for extended period of hospitalization. 
Guidelines and regulatory standards of research involving human beings were observed, according to resolution no. 466 of December 2012 of the Brazilian National Health Council. The research project was approved by the Research Ethics Committee of the Ribeirão Preto, College of Nursing at the Universidade de São Paulo, under protocol no. 603.228/2013. CAAE: 20111213.3.3001.5440.

The study population was made up of nurses, nursing technicians, and nursing aides who worked in one of the five studied hospitalization units and provided direct care to patients. The collection occurred in the three work shifts, and saliva and nasal secretion samples of 100 professionals were obtained in three periods (months zero, four, and eight). Professionals who did not participate in the three data collection stages were excluded.

Data collection occurred from April 2014 to February 2015 during their own shifts and workplaces, by means of application of a semistructured instrument with average duration from 15 to 20 minutes, carried out by the researcher and four assistants in a private room. The instrument contained questions associated with demographic, professional, and individual aspects, and was previously submitted to face and content evaluation and adjustment by three specialists with experience in research on infectious diseases.

In order to obtain saliva and nasal secretion samples of the nursing professionals, they were asked to put from three to five milliliters of saliva directly in a graduated, dry, and sterile test tube. Nasal secretions were obtained with the help of a dry swab introduced in both nostrils, by means of three clockwise circular movements.
The material was seeded on blood agar and mannitol, and the collected samples were processed in the microbiology and serology laboratory of the studied hospital. Afterwards, the automated system Vitek ${ }^{\circledR} 2$ (BioMérieux ${ }^{\mathrm{TM}}$, France) was used, by means of GP Test Kit Vitek ${ }^{\circledR} 2$ cards for identification of gram-positive bacteria. AST P585 (BioMérieux ${ }^{\mathrm{TM}}$, France) cards were used to identify and evaluate Staphylococcus aureus susceptibility to antibiotics.

The data were organized in Microsoft Office Excel for Windows 2013 and analyzed through the IBM® SPSS 20 software. For data analysis, descriptive statistics with measures of central tendency (mean and median) and dispersion (standard deviation) was used.

The carrier state of nursing professionals considered in this study was consistent with that proposed by other authors. ${ }^{17}$ The numerator was the total of positive samples, and the denominator was the total number of samples collected from each individual. Therefore, professionals were considered persistent carriers when they presented two or three positive samples for Staphylococcus aureus, and transitory carriers when they presented a single sample. Non-carriers were those who presented three negative cultures for this microorganism.

The professionals identified as colonized were reported on the culture results and, upon agreement, they were referred to the hospital infection control committee (HICC) of the institution to proceed with the conduct required.

\section{RESULTS}

Table 1 presents demographic and professional characteristics of the 100 participants in the study.

Table 1 - Distribution of nursing professionals according to demographic and professional characteristics. Ribeirão Preto, São Paulo, Brazil, 2014-2015. (n=100)

\begin{tabular}{llcc}
\hline & Variables & $\mathbf{n}$ & $\mathbf{\%}$ \\
\hline \multirow{3}{*}{ Professional category } & Nurse & 19 & 19.0 \\
& Nursing technician & 22 & 22.0 \\
Gender & Nursing aide & 59 & 59.0 \\
& Female & 79 & 79.0 \\
& Male & 21 & 21.0 \\
Age (years) & 20 to 39 & 09 & 9.0 \\
& 30 to 39 & 36 & 36.0 \\
& 40 to 49 & 39 & 39.0 \\
& $\geq 50$ & 16 & 16.0
\end{tabular}




\begin{tabular}{lllc} 
Lopes LP, Pio SPM, Reinato LAF, Gaspar GG, Prado MA, Gir E & & & $4 / 8$ \\
\hline & Variables & n & $\%$ \\
\hline \multirow{3}{*}{ Education level } & Complete high school & 68 & 68.0 \\
& Complete higher education & 22 & 22.0 \\
& Complete graduate degree & 10 & 10.0 \\
Work shift & Day & 37 & 37.0 \\
& Night & 28 & 28.0 \\
& Rotating shift & 35 & 35.0 \\
Length of time in the profession (years) & $<05$ & 15 & 15.0 \\
& 05 to 14 & 43 & 43.0 \\
Work in another institution & $\geq 15$ & 42 & 42.0 \\
\multirow{2}{*}{ Weekly working hours } & Yes & 14 & 14.0 \\
& No & 86 & 86.0 \\
& 30 to 36 & 43 & 43.0 \\
\hline
\end{tabular}

With regard to nasal secretion and saliva samples of the 100 participants, 600 samples in total were collected and processed, being three nasal secretion samples and three saliva samples from each nursing professional. The mean interval between the collections was four months.

In the present study, 57 (57.0\%) professionals were classified as non-carriers of Staphylococcus aureus and $43(43.0 \%)$ presented at least one positive saliva or nasal secretion culture for Staphylococcus aureus in the three periods of collection. Among the carriers, $36(83.7 \%)$ presented methicillin-sensitive Staphylococcus aureus (MSSA) and seven (16.3\%) presented methicillin-resistant Staphylococcus aureus (MRSA).

According to Table 2, of the $32(32.0 \%)$ participants colonized in the nasal area, $16(50.0 \%)$ were persistent carriers and the others were transitory carriers. Regarding persistent carriers, 11 (11/16) had the microorganism isolated in two samples and five nursing professionals had it isolated in the three nasal secretion samples. The only professional colonized exclusively in the saliva sample was classified as a transitory carrier.

With regard to the ten colonized professionals (nasal and saliva), seven $(7 / 10)$ were considered persistent carriers by the nasal secretion sample. Of these, in four (4/7), Staphylococcus aureus was isolated in the three samples and, in three $(3 / 7)$ professionals, it was isolated in two nasal secretion samples. The only professional who was considered a saliva persistent carrier had the microorganism isolated in two samples.

Table 2 - Distribution of nursing professionals colonized by Staphylococcus aureus, according to colonization areas and carrier state. Ribeirão Preto, São Paulo, Brazil, 2014-2015. (n=43)

\begin{tabular}{|c|c|c|c|c|c|c|c|c|}
\hline Colonization areas & ${ }^{*} \mathbf{N}_{\mathrm{P}}$ & ${ }^{t} S_{P}$ & $\ddagger \mathbf{N}_{\mathrm{T}}$ & $\S_{\mathrm{T}}$ & ${ }^{1} \mathbf{N}_{\mathrm{T}} \mathbf{S}_{\mathrm{T}}$ & ${ }^{\top} \mathbf{N}_{\mathrm{P}} \mathbf{S}_{\mathrm{T}}$ & ${ }^{* *} \mathbf{N}_{\mathrm{T}} \mathrm{S}_{\mathrm{P}}$ & Total \\
\hline Nasal & 16 & - & 16 & - & - & - & - & 32 \\
\hline Saliva & - & - & - & 01 & - & - & - & 01 \\
\hline Nasal and saliva & - & - & - & - & 02 & 07 & 01 & 10 \\
\hline Total & 16 & 0 & 16 & 01 & 02 & 07 & 01 & 43 \\
\hline
\end{tabular}

${ }^{*} \mathrm{~N}_{\mathrm{P}}$ : nasal persistent; ${ }^{\dagger} \mathrm{S}_{\mathrm{P}}$ : saliva persistent; ${ }^{\ddagger} \mathrm{N}_{\mathrm{T}}$ : nasal transitory; ${ }^{\circledR} \mathrm{S}_{\mathrm{T}}$ : saliva transitory; $"{ }^{\prime} \mathrm{N}_{\mathrm{T}} \mathrm{S}_{\mathrm{T}}$ : nasal transitory and saliva transitory; ${ }^{\mathbb{}} \mathrm{N}_{\mathrm{P}} \mathrm{S}_{\mathrm{T}}$ : nasal persistent and saliva transitory; ${ }^{* *} \mathrm{~N}_{\mathrm{T}} \mathrm{S}_{\mathrm{P}}$ : nasal transitory and saliva persistent

Considering the colonization by MRSA, $100.0 \%$ were nasal carriers of Staphylococcus aureus. Of these, $57.1 \%(4 / 7)$ were classified as transitory carriers, that is, they presented a single nasal secretion sample colonized by MRSA, and 42.9\% (3/7) were classified as persistent carriers, with two or three positive samples. Of the three professionals considered persistent carriers, it was observed that in one of them Staphylococcus aureus was detected in three nasal secretion samples. The two profession- 
als colonized by MRSA in the saliva sample were considered transitory carriers; in addition to being saliva carriers, they were also nasal carriers.

Of the 43 nursing professionals considered transitory or persistent carriers of Staphylococcus aureus in the saliva or nasal secretion samples, 53.5\% were nursing aides, $25.6 \%$ were nursing technicians, and $20.9 \%$ were nurses.

An antibiogram was carried out to identify the susceptibility profile of Staphylococcus aureus to antimicrobials. In the total, 74 nasal secretion samples and 12 saliva samples isolated with Staphylococcus aureus were identified. Of the 74 nasal secretion samples, $14.9 \%(11 / 74)$ presented oxacillin resistance; $91.9 \%(68 / 74)$ presented penicillin resistance; $44.6 \%$ (33/74) presented erythromycin resistance; $41.9 \%(31 / 74)$ presented clindamycin resistance; $5.4 \%$ (4/74) presented ciprofloxacin and chloramphenicol resistance; $4.1 \%$ (3/74) presented tetracycline resistance; $2.7 \%(2 / 74)$ presented trimethoprim-sulfamethoxazole (TMP-SMX) resistance; and gentamicin, rifampicin, and vancomycin resistance was not found. Among the 12 isolated Staphylococcus aureus saliva samples of professionals, $16.7 \%$ (2/12) were oxacillin resistant; $100.0 \%$ $(12 / 12)$ penicillin resistant; $33.4 \%$ (4/12) erythromycin resistant; $25.0 \%$ (3/12) clindamycin resistant, and no ciprofloxacin, chloramphenicol, gentamicin, rifampicin, TMP-SMX, tetracycline, and vancomycin resistance (Figure 1) was found.

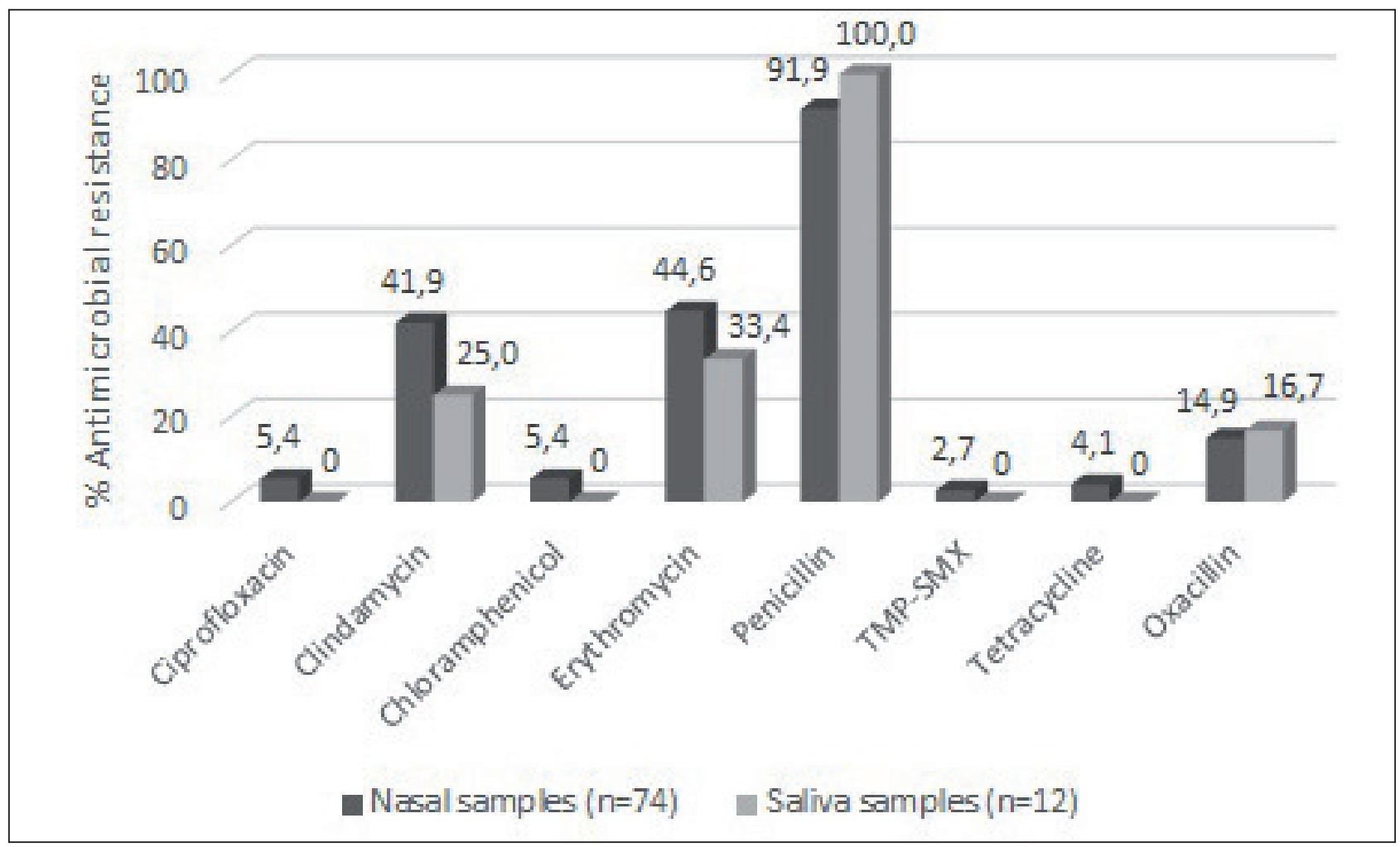

Figure 1 - Resistance profile of Staphylococcus aureus isolated from saliva and nasal secretion samples of nursing professionals to antimicrobials. Ribeirão Preto, São Paulo, Brazil, 2014-2015

\section{DISCUSSION}

Human beings are considered reservoirs of numerous microorganisms. Among these microorganisms, Staphylococcus aureus stands out as a relevant human pathogen, because it is responsible for several infections and has a high infectious potential. ${ }^{11,18}$

Colonization by Staphylococcus aureus often occurs in the anterior nasopharynx compared to the oropharynx. ${ }^{11}$ Another study ${ }^{19}$ showed that the nostrils were the main colonization areas by MRSA. However, screening tests in different anatomic areas are recommended, since in that study, $40.3 \%$ of the individuals colonized by MRSA presented negative cultures in the nostrils and positive cultures in the oral cavity, groin, armpit, perineum, and other areas. ${ }^{19}$

Healthcare professionals, in addition to being potential carriers and disseminators of microor- 
ganisms in their work environment, are also considered vehicles of transmission between patients and comunities. ${ }^{4}$

Studies show that healthcare professionals, as well as their families and those who are in contact with them, are potentially at risk of infection by pathogen agents, including MRSA. ${ }^{2,8}$

Asymptomatic individuals colonized by Staphylococcus aureus may spread the microorganism in their work environment and contribute to its colonization among susceptible individuals. ${ }^{10}$

A study carried out to determine the prevalence of asymptomatic carriers of Staphylococcus aureus among healthcare professionals showed a high rate of nasal colonization, since 112 of the 256 $(43.8 \%)$ healthcare professionals were colonized by this microorganism. Of these, 51 (45.5\%) were nurses. ${ }^{20}$ Another study identified nasal colonization in nursing professionals and showed a prevalence of Staphylococcus aureus, representing $23.0 \%$ of the identified bacteria. ${ }^{21}$

In the present study, $43.0 \%$ of nursing professionals were characterized as Staphylococcus aureus carriers, with $83.7 \%(36 / 43)$ being MSSA and $16.3 \%$ $(07 / 46)$ MRSA. Similar results were found in a study ${ }^{1}$ that investigated the presence of Staphylococcus aureus in the nursing team's saliva in a teaching hospital in a city in the state of São Paulo. In that study, $41.0 \%$ of nursing professionals presented colonization by Staphylococcus aureus, with $72.2 \%$ being MSSA and 17.4\% MRSA.

The knowledge of professionals on their carrier state enables the adoption of isolation measures, thus preventing the dissemination of these microorganisms in healthcare services.

Nursing aides were the professionals with the highest number of Staphylococcus aureus carriers $(53.5 \%)$. This is expected, because in addition to being the most present category in healthcare institutions, nursing aides perform tasks that constantly require physical contact with patients, such as hygiene and comfort care. This physical contact, combined with non-adherence to standard precautions make professionals more vulnerable to colonization by microorganisms. ${ }^{1}$

An important characteristic of Staphylococcus aureus is its ability to acquire resistance mechanisms to antibiotics. It has developed resistance to practically all types of antibiotics available for clinical use. The development of this resistance is directly associated with the wide and indiscriminate use of antimicrobials. ${ }^{13}$
The Brazilian National Health Surveillance Agency, in response to the increase in inappropriate and indiscriminate use of antimicrobials launched resolution RDC no. 44 of October 26, 2010, establishing that the dispensing and sale of antimicrobials in the country can only be carried out upon special control prescriptions in two copies. ${ }^{22}$

It is worth mentioning that Staphylococcus aureus isolated from saliva and nasal secretion samples presented resistance to 8 of the 11 antimicrobials evaluated. Other studies ${ }^{3,9,23}$ showed a high penicillin and ery thromycin resistance rate, corroborating the results in this study regarding antibiotics.

Strategies adopted by healthcare services to control the existence of resistant strains due to the indiscriminate use of antimicrobials involve the nondistribution of antimicrobials and restriction on certain drugs of broad spectrum of action, allowing their release only after previous authorization from HICC physicians. ${ }^{24}$

A study carried out in the state of Paraná highlighted the importance of a deeper approach of subjects associated with the prevention and control of infections, as a strategy to promote patient safety in the training process of healthcare professionals. ${ }^{25}$ The implementation of preventive strategies that seek to improve quality of care, by means of rigorous control of care procedures, epidemiological surveillance actions, identification of patients at risk, and follow-up of cases, helps reducing healthcareassociated infection rates. ${ }^{26}$

This study presented limitations with regard to its population and place of study. The population was made up of a specific group of healthcare professionals and the study was carried out in a large and high complexity teaching institution, which may limit the generalization of the results to other professional categories and healthcare institutions.

\section{CONCLUSION}

The results evidenced the colonization of nursing professionals by Staphylococcus aureus, isolated from their saliva and nasal secretion, as well as the resistance of these bacteria to antimicrobials. Likewise, these results suggest the implementation of health policies that have an impact on the standardization and careful use of antimicrobials in clinical practices; as well as the adherence of professionals to prevention and control measures in the epidemiological chain of these microorganisms, in compliance with current guidelines. Knowledge of healthcare professionals on their 
condition of carriers is important, because it may contribute to a reflection and change of attitude in professional practice.

\section{REFERENCES}

1. Moura JP, Pimenta FC, Hayashida M, Cruz EDA, Canini SRMS. A colonização dos profissionais de enfermagem por Staphylococcus aureus. Rev LatinoAm Enfermagem. 2011 Mar-Abr; 19(2):325-31.

2. Albrich, WC, Harbarth S. Health-care workers: source, vector, or victim of MRSA? Lancet Infect Dis. 2008 May; 8(5):289-301.

3. Carvalho MJ, Pimenta FC, Hayashida M, Gir E, Silva AM, Barbosa CP, et al. Prevalence of methicillinresistant and methicillin-susceptible $S$. aureus in the saliva of health professionals. Clinics. 2009 Apr; 64(4):295-302.

4. Cruz EDA, Pimenta FC, Palazzo ICV, Darini ALC, Gir E. Prevalência de Staphylococcus aureus na saliva de trabalhadores de saúde. Colomb Med. 2011 Abr-Jun; 42 (Supl 1):10-6.

5. Gebreyesus A, Gebre-Selassie S, Mihert A. Nasal and hand carriage rate of methicillin resistant Staphylococcus aureus (MRSA) among health care workers in Mekelle Hospital, North Ethiopia. Ethiop Med J. 2013 Jan; 51(1):41-7.

6. Ohadian-Moghadam S, Pourmand MR, Davoodabadi A. The detection of mupirocin resistance and nasal carriage of methicillin resistant Staphylococcus aureus among healthcare workers at University Hospitals of Tehran, Iran. Iran J Public Health. 2015 Mar; 44(3):361-8.

7. Moura JP, Gir E, Rosa JO, Belíssimo-Rodrigues F, Cruz EDA, Oliveira ACA, et al. Resistência à mupirocina entre isolados de Staphylococcus aureus de profissionais de enfermagem. Acta Paul Enferm. 2010 Mar-Abr; 23(3):399-403.

8. Otter JA, French GL. Community-associated meticillinresistant Staphylococcus aureus strains as a cause of healthcare-associated infection. J Hosp Infect. 2011 Nov; 79(3):189-93.

9. Silva ECBF, Samico TM, Cardoso RR, Rabelo MA, Bezerra-Neto AM, Melo FL, et al. Colonização pelo Staphylococcus aureus em profissionais de enfermagem de um hospital escola de Pernambuco. Rev Esc Enferm USP. 2012 Fev; 46(1):132-7.

10. Sivaraman K, Venkataraman N, Cole AM. Staphylococcus aureus nasal carriage and its contributing factors. Future Microbiol. 2009 Oct; 4(8):999-1008.

11. Kluytmans J, Van-Belkum A, Verbrugh H. Nasal carriage of Staphylococcus aureus: epidemiology, underlying mechanisms, and associated risks. Clin Microbiol Rev. 1997 Jul; 10(3):505-20.

12. Chacko J, Kuruvila M, Bhat GK. Factors affecting the nasal carriage of methicillin-resistant Staphylococcus aureus in human immunodeficiency virus-infected patients. Indian J Med Microbiol. 2009 Apr-Jun; 27(2):146-8.

13. Santos AL, Santos DO, Freitas CC, Ferreira BLA, Afonso IF, Rodrigues CR, et al. Staphylococcus aureus: visitando uma cepa de importância hospitalar. J Bras Patol Med Lab. 2007 Dez; 43(6):413-23.

14. Jevons PM. “Celbenin" - resistant staphylococci. Br Med J. 1961 Jan; 1(5219):124-5.

15. Simor AE. Containing methicillin-resistant $S$ aureus. Surveillance, control, and treatment methods. Postgrad Med. 2001 Oct; 110(4):43-8.

16. Santos NQ. A resistência bacteriana no contexto da infecção hospitalar. Texto Contexto Enferm. 2004; 13(esp):64-70.

17. Nilsson P, Ripa T. Staphylococcus aureus throat colonization is more frequent than colonization in the anterior nares. J Clin Microbiol. 2006 Sep; 44(9):3334-9.

18. Lim CJ, Cheng AC, Kennon J, Spelman D, Hale D, Melican G, et al. Prevalence of multidrug-resistant organisms and risk factors for carriage in longterm care facilities: a nested case-control study. J Antimicrob Chemother. 2014; 69(7):1972-80.

19. Farley JE, Hayat MJ, Sacamano PL, Ross T, Carroll K. Prevalence and risk factors for methicillin-resistant Staphylococcus aureus in an HIV-positive cohort. Am J Infect Control. 2015 Apr; 43(4):329-35.

20. Elie-Turenne MC, Fernandes H, Mediavilla JR, Rosenthal M, Mathema B, Singh A, et al. Prevalence and characteristics of Staphylococcus aureus colonization among healthcare professionals in an urban teaching hospital. Infect Control Hosp Epidemiol. 2010 Jun; 31(6):574-80.

21. Reinato LAF, Pereira FMV, Lopes LP, Pio DPM, Gir E. Nasal colonization in nursing professionals from units specialized in HIV / AIDS. Rev Bras Enferm. 2015 Mar-Apr; 68(2):320-4.

22. Agência Nacional de Vigilância Sanitária. Resolução da Diretoria Colegiada - RDC n ${ }^{\circ} .44$, de 26 de outubro de 2010. Dispõe sobre o controle de medicamentos à base de substâncias classificadas como antimicrobianos, de uso sob prescrição médica, isoladas ou em associação e dá outras providências. Diário Oficial da União 2010; 27 out.

23. Moreira ACMG, Santos RR, Bedendo J. Prevalência e perfil de sensibilidade de Staphylococcus aureus isolados em pacientes e equipe de enfermagem. Cienc Cuid Saude 2013 Jul-Set; 12(3):572-9.

24. Marra AR, Almeida SM, Correa L, Silva M Jr., Martino $\mathrm{MD}$, Silva CV, et al. The effect of limiting antimicrobial therapy duration on antimicrobial resistance in the critical care setting. Am J Infect Control. 2009 Apr; 37(3):204-9.

25. Belela-Anacleto ASC, Sousa BC, Yoshikawa JM, Avelar AFM, Pedreira MLG. Hand hygiene and patient 
safety: perspectives of professors and undergraduate students. Texto Contexto Enferm [Internet]. 2013 OutDez [cited 2016 Oct 17]; 22(4):901-8. Available from: http:/ / www.scielo.br/scielo.php?script=sci_arttext \&pid=S0104-07072013000400005

26. Souza ES, Belei RA, Carrilho CMDM, Matsuo T,
Yamada-Ogatta SF, Andrade G, et. al. Mortalidade e riscos associados a infecção relacionada à assistência à saúde. Texto Contexto Enferm [Internet]. 2015 Jan-Mar Dez [cited 2016 Oct 17]; 24(1):220-8. Available from: http://www.scielo.br/pdf/tce/v24n1/pt_0104-0707tce-24-01-00220.pdf 